\title{
History of the Leech Trade in Ireland, 1750-1915: Microcosm of a Global Commodity
}

\author{
ROY T. SAWYER* \\ Medical Leech Museum, Bryngelen House, 2 Bryngwili Road, Hendy, Pontarddulais, \\ Swansea SA4 0XT, UK
}

\begin{abstract}
In the nineteenth century the medicinal leech Hirudo medicinalis evolved into a lucrative commodity in great demand throughout the western world. In less than a century its trade became big business by any measure, involving tens of millions of animals shipped to every inhabited continent. In this context Ireland is particularly instructive in that it was the first country in Europe to exhaust its supply of native leeches. Concomitantly, it was also the first country to import leeches from abroad, as early as 1750 . Being an island with manageable border controls, and a clearly definable medical market, Ireland serves superbly as a microcosm of the leech as a worldwide commodity. Being a relative small country it is possible for the first time to gain a balanced perspective of various economic factors underlying this trade, including supply and demand, exploitation of natural resources, and an evolving network of competitive traders.

This paper addresses these and other aspects of the leech trade in Ireland. The principal, and unexpected, finding of this paper is that leeches were unequivocally very expensive in Ireland and became a significant drain on hospital budgets. As such, they found little use amongst the Irish poor. An estimate of several million leeches were imported into Ireland in the nineteenth century, a practice which continued into the twentieth. They were imported initially from Wales and then from France following the defeat of Napoleon, but the bulk came ultimately from Hamburg, via importers in England.
\end{abstract}

Keywords: Hirudo medicinalis, Leeches, Ireland, Dublin, Belfast, Commodity

\section{Introduction}

In the nineteenth century several medical products were in such demand worldwide they attained the status of globally traded commodities. Although these were of considerable economic importance, little is understood about how this immense trade influenced

\footnotetext{
* Email address for correspondence: leechmuseum@compuserve.com
}

Many individuals and institutions assisted in the research for this paper. I would particularly like to acknowledge Harriet Wheelock, Archivist, Royal College of Physicians of Ireland, Dublin, and Mary O'Doherty, Archivist, The Mercer Library, Royal College of Surgeons in Ireland, Dublin. 
medical practice at the local level, and vice-versa. ${ }^{1}$ By way of example, one of the best known of these commodities was quinine, an effective treatment for malaria. The bark of the Cinchona tree was produced in enormous quantities in Peru and other tropical countries and shipped to malaria-afflicted markets throughout the world. While the history of quinine is well documented, ${ }^{2}$ the commercial interaction between specific suppliers in tropical plantations on the one hand, and medical practitioners up to thousands of miles away on the other, remains obscure. In this context, a clearer understanding of the global medical marketplace in the nineteenth century can be gained by focussing on a heretofore neglected, but well-documented medical commodity (medicinal leeches), and by confining questions to a manageable geographical region (Ireland).

In the nineteenth century the European medicinal leech Hirudo medicinalis evolved into a lucrative commodity in great demand for medicine throughout the western world. In less than a century its trade became big business by any measure, involving tens of millions of leeches. The demand for leeches in western Europe soon led to the exhaustion of local sources, resulting in importation from increasingly further afield and, inevitably, to a complex commercial network.

Ireland is particularly instructive in analysing the history of the leech trade in that it is a relatively small island with a clearly definable medical market, and with manageable border controls. Furthermore, it was the first country in Europe to exhaust its supply of native leeches and, concomitantly, it was also the first country to import leeches from overseas, as early as 1750. For these and other reasons Ireland serves superbly as a baseline study for asking further questions of the leech trade within a much wider medical context.

The following research attempts a balanced perspective of economic, financial and political factors underlying the Irish leech trade. The principal questions asked in this paper are: who ultimately purchased the leeches and how much did they cost? Who were the dealers that imported leeches from overseas and sold them locally? Where did the leeches originate and how did they get to Ireland? And how did Ireland's political relationships with mainland Britain and other countries in Europe affect the leech trade? This paper addresses these and other aspects of the leech trade in Ireland, with particular focus on the competing cities of Dublin and Belfast. Since leeches were so pervasive in nineteenth century medicine, many findings in this paper are also integral to a general understanding of the history of medicine in Ireland. ${ }^{3}$

Productive sources of commercial information on the Irish leech trade included ledgers of hospitals, dispensaries and chemists in Dublin and Belfast. These and other documents were accessible in archives in Ireland and Britain for which the author is very grateful. These were notably the Royal College of Physicians of Ireland, Royal College of Surgeons of Ireland, National Library of Ireland, Public Record Office of Northern Ireland (PRONI), National Archives (Kew, UK) and the Wellcome Library (London). A comprehensive list of leech dealers of the period was identified mainly from municipal directories and

\footnotetext{
${ }^{1}$ For a seminal study of the medical marketplace see H.J. Cook, Matters of Exchange: Commerce, Medicine, and Science in the Dutch Golden Age (New Haven, CT: Yale University Press, 2007).

${ }^{2}$ For example, K.P. Prabhakaran Nair, The Agronomy and Economy of Important Tree Crops of the Developing World (London: Elsevier, 2010), 112-29.

${ }^{3}$ For example, J.F. Fleetwood, The History of Medicine in Ireland, 2nd edn (Dublin: The Skellig Press, 1983); R.S. Allison, The Seeds of Time, Being a Short History of the Belfast General and Royal Hospital 1850/1903 (Belfast: Brough, Cox and Dunn Ltd, 1972); D.H. Craig, 'A History of the Belfast City Hospital', Ulster Medical Journal, 43, 1 (1974), 1-11.
} 
newspaper archives, especially the Freeman's Journal (Dublin) and the Belfast Newsletter (Belfast).

The Dublin Journal of Medical Science and other Irish medical publications at this time were replete with case studies in which numerous leeches were applied. However, an account of leech therapeutics per se, let alone its justification, lies outside the scope of this paper. ${ }^{4}$ More to the point, the large-scale use of leeches created an enormous demand for leeches in Ireland, and thereby constituted the starting point for this mainly microeconomic study.

\section{'Erin, Leech Thyself'}

The use of leeches in Dublin increased forty-five fold between 1780 and 1836. In a remarkably modern statistical paper for its time (1836), William D. Moore (1813-71) analysed the prescriptions of his grandfather, Dr Daniel Moore, over a period of nearly sixty years. ${ }^{5}$ The data were categorised into three eighteen-year periods based on 1,200 prescriptions each. The leech prescriptions for each period were as follows: one (1780-98), twenty (1799-1817) and forty-five (1818-36). Moore attributed the latter increase largely to the bloodletting enthusiasm of the influential French surgeon F.J.V. Broussais (1772-1838). ${ }^{6}$

An additional Irish factor for the exponential increase in leeching was that, for socioeconomic reasons, Ireland suffered disproportionately with cholera, typhoid, typhus, ophthalmic and other epidemics, as well as incomparable famine-related diseases. Perversely, such epidemics were a boon to Ireland's leech traders. For example, during the Irish cholera epidemic of 1832, a prominent leech dealer, Charles Keenan, sold a remarkable $£ 38 / 1 / 0^{7}$ or approximately 2,700 leeches to Townsend Street Cholera Hospital, Dublin, in only six months (May-October 1832). ${ }^{8}$

In an epidemic of puerperal fever, Dr Robert Collins (1801-68) recommended in his Practical Treatise of Midwifery to treat this fever in Dublin's maternity Rotunda Hospital, as follows:

Where the state of the patient was such as to encourage a general bleeding, we used the lancet; I am satisfied, however, that in hospital, the immediate application of three or four dozen leeches, followed by a warm bath... will be found in the great majority the most judicious means of removing blood.... The leeches and bath must be repeated at the expiration of $4,5,6$ hours or longer.... We have in numerous instances applied leeches in this way to the extent of $10,12,14$, and in some 16 dozen [leeches]. ${ }^{9}$

\footnotetext{
${ }^{4}$ For accounts of the history of the medical use of leeches see R.G.W. Kirk and N. Pemberton, 'Re-imagining Bleeders: The Medical Leech in the Nineteenth Century Bloodletting Encounter', Medical History, 55 (2011), 355-60; I.S. Whitaker et al., 'Hirudo medicinalis: Ancient Origins of, and Trends in the Use of Medicinal Leeches Throughout History', British Journal of Oral and Maxillofacial Surgery, 42 (2004), 133-7; R.T. Sawyer, 'Johann Friedrich Dieffenbach: Successful Use of Leeches in Plastic Surgery in the 1820s', British Journal of Plastic Surgery, 53 (2000), 245-7; and S.L. Adams, 'The Medical Leech: A Page from the Annelids of Internal Medicine', Annals of Internal Medicine, 109 (1988), 399-405.

${ }^{5}$ William D. Moore, 'Statistical View of the Comparative Frequency in Which the Principle Medicines Used During the Last Sixty Years Have Been Prescribed in Dublin', Dublin Journal of Medical Science, 10, 1 (1836), 24-32.

${ }^{6}$ For a recent account of Broussais's influence, see Kirk and Pemberton, op. cit. (note 4).

7 The abbreviation $£ 38-1-0$ (sometimes written $£ 38$ 1s 0d) represents 38 pounds, one shilling, zero pence in the

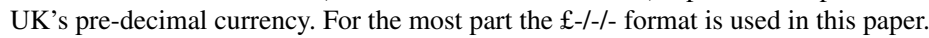

${ }^{8}$ Receipt and Expenditure of Central Board of Health for Ireland and City of Dublin (London: House of Commons, 3 July 1834), 20.

${ }^{9}$ Robert Collins, A Practical Treatise on Midwifery, Containing the Result of Sixteen Thousand Six Hundred and Fifty-four Births (Philadelphia, PA: Barrington, and Haswell, 1838), 194-5.
} 
Ear specialist Dr William R. Wilde (1815-76), better known as the father of Oscar Wilde, was founder and surgeon of St Mark's Ophthalmic Hospital in Dublin, and later oculist to Queen Victoria in Ireland. In 1851 he was called to report on a serious epidemic ophthalmia in Tipperary, Athlone and other workhouses. The outbreak occurred primarily among children who laboured under unsanitary conditions, recognised by Wilde at the time as a root cause of the disease. In an immensely influential report Wilde strongly recommended that leeches be applied to the area around a child's eye as soon as disease symptoms arose. However, he pointed out a practical problem in using leeches in understaffed workhouses in 'that where leeching is to be used in many cases it will require a larger staff of attendants than is generally allowed for Poor-Law Hospitals'. ${ }^{10}$

By the beginning of the nineteenth century the Irish physicians and surgeons considered themselves above the 'menial offices of applying leeches, and administering clysters, \&c'. This role was assumed increasingly by the apothecary with the effect that, in time, 'the medical profession itself had consigned the apothecary the offices of applying leeches, $\& c ' .{ }^{11}$ By the $1830 \mathrm{~s}$ - or probably much earlier - the Irish apothecary - that is, a Licentiate of Apothecaries' Hall, Dublin - claimed exclusivity to bleed, leech and cup patients:

\author{
Messrs Pring and Co \\ New Medical Hall \\ 30, Westmoreland Street \\ Instituted Aug 12, 1821... \\ Cupping, bleeding, the application of leeches, \&c, which \\ are peculiar to the Apothecary alone, will at all times receive \\ the strictest attention; and as Mr Pring presumes not to visit, or \\ prescribe externally on patients, his attendance at home may \\ at all times be relied on. \\ N.B. There is a vacancy at present for a young gentleman \\ (properly qualified) as an Apprentice ${ }^{12}$
}

The contemporary role of the Licentiate Apothecary in the context of leeching was summarised as follows: 'Mr Porter considered that the duties of the apothecaries [in the South Dublin Union] would be to compound such medicines as the physician should prescribe, and attend to the application of leeches and blisters whenever required' ${ }^{13}$ The apothecary was also available to the public to apply leeches at short notice, even at unsocial hours. A case in point concerns an altercation one dark evening in a Dublin boarding house which resulted in a black eye and related injuries: 'He did not return the blows he received, but went immediately to an apothecary's, and had leeches applied to the injured parts'. ${ }^{14}$ Joseph Mulholland, apothecary at the Lunatic Asylum, Belfast, also sold leeches to the public, ${ }^{15}$ but generally apothecaries, as regular users of leeches, were targeted by leech dealers as valuable customers rather than competitors.

Two prominent apothecary/chemists located very near each other in the centre of Dublin, but on either side of the River Liffey, competed aggressively. Both Bewly and

\footnotetext{
${ }^{10}$ William Robert Wills Wilde, 'On the Epidemic Ophthalmia Which Has Prevailed in the Workhouse and Schools of the Tipperary and Athlone Unions', London Journal of Medicine, 3, 25 (1851), 17-43.

${ }^{11}$ Anonymous, 'Irish College of Surgeons and Apothecaries' Hall', London Medical Gazette, New Series, 1 (1838), 733, 942.

12 Nation (Dublin), 6 March 1847.

${ }^{13}$ Freeman's Journal (Dublin), 9 January 1852.

${ }^{14}$ Freeman's Journal (Dublin), 30 October 1839.

15 Public Records Office of Northern Ireland (PRONI), D1748/G/479, 30 July 1836; Belfast Newsletter (Belfast), 14 April 1837.
} 
Evans of 3 Lower Sackville Street (now O'Connell St), and Messrs Pring and Co of the New Medical Hall, 30 Westmoreland Street, sold a full range of medical supplies and services. This included the application of leeches which, to judge from the space allocated to them, was quite lucrative. In the spring and summer of 1847 something happened whereby these two firms advertised aggressively in the local newspaper Nation. ${ }^{16,17}$ Pring's especially lengthy ad hinted this was 'in consequences of a recent arrangement entered into by the principal medical establishments of this city...' . Furthermore, 'Being their own importers and manufacturers, the Proprietors can challenge the competition of any similar establishment, with regard to genuineness of articles or moderation of price'.

Perhaps the most prominent apothecary in Ireland was Charles Butler who in the 1820s frequently advertised his services for cupping, venesection and application of leeches from his prestigious address on Lower Sackville Street, Dublin. He was remarkable for his meteoric rise in qualifications, as well as social status: Licentiate Apothecary of London (1820), Licentiate of Dublin and London (1821), MD, Apothecary and Chemist to his Majesty (1823), and MD, Apothecary and Chemist to his Majesty and the Lord Lieutenant (1824). ${ }^{18}$ In essence, Butler became licensed to apply leeches to King George IV whose earlier leeching, in 1816, had been prominently posted in Dublin's Freeman's Journal: 'His Royal Highness has lost much blood; at one time no less than 36 leeches were applied'. 19

\section{The Leech Trade in Ireland: Bloodsuckers From Overseas}

Ireland is the only country in which Hirudo medicinalis has apparently become extinct. ${ }^{20}$ In the 1600s and 1700s several specific lakes and marshes, notably Lough Mask and Blarney Lough, were claimed as sources of leeches used medicinally in Dublin and Cork. However, as shown elsewhere, the native Irish leech disappeared gradually, and finally disappeared from the historic record. ${ }^{21}$

As one contemporary Dublin surgeon observed, somewhat sardonically,

We should bewail as a national calamity that they [leeches] are not produced in our own country, and amongst the kind dispensations of Providence, hail our contiguity to Britain, that we may be supplied with her bloodsuckers as remedies for all our maladies. ${ }^{22}$

Irish doctors had significant difficulty getting enough leeches to supply their needs until the end of the war with France, a watershed event for the leech trade. Even then the availability of imported leeches was unreliable, as observed by Dubliner Charles Butler in his popular Medicine Chest Directory: 'Since leeches have been so much in demand,

\footnotetext{
${ }^{16}$ Nation (Dublin), 1847 (8 May; 5, 12, 16, 19 June; 17 July; 21 August). Bewley and Evans 'Bleeding, cupping, the application of leeches, and every office within the province of an Apothecary, promptly attended to...'.

${ }^{17}$ Nation (Dublin), 1847 (6, 20 March; 3 April; 15, 22 May; 5, 19 June; 17 July). Messrs Pring and Co, 'Cupping, bleeding, the application of leeches, \&c, will at all times receive the strictest attention...'.

18 Freeman's Journal (Dublin), 7 February 1820; 10 January 1821; 13 January 1823; 18 February 1824.

${ }^{19}$ Freeman's Journal (Dublin), 28 August 1816.

${ }^{20}$ T.K. McCarthy, 'Observations on the Distribution of the Freshwater Leeches (Hirudinea) of Ireland', Proceedings of the Royal Irish Academy, Section B, 75 (1975), 401-50; Convention on International Trade in Endangered Species of Wild Fauna and Flora. 22nd Meeting of the Animals Committee, Lima (Peru), 7-13 July 2006. AC22 Doc. 11.3 (Rev. 1), 8.

${ }^{21}$ R.T. Sawyer, 'Re-assessment of the Medicinal Leech, Hirudo medicinalis Linnaeus, 1758, in Ireland', Zoosystema, 35 (2013), 113-25.

22 Freeman's Journal (Dublin), 22 May 1812.
} 
the supply, being dependant upon weather, is very uncertain; and in extreme dry or frosty weather they are sometimes not to be had...'.23

\section{Welsh Leeches}

As early as 1750 Charles Smith, MD, recorded that leeches were being imported into Ireland from adjacent Wales. ${ }^{24}$ In fact, this is the earliest record of leech importation from overseas anywhere in the British Isles. Smith's observation was corroborated in 1772 by another Dublin doctor, John Rutty, who gave more detail regarding the Welsh leeches, 'for which the seas are crossed every year, in order to furnish Dublin' ${ }^{25}$ Importation from Wales reportedly continued up to 'a few years' prior to $1830,{ }^{26}$ but by 1849 apothecary Michael Donovan declared 'they have nearly, if not entirely, disappeared from that country [ie. Wales]'. ${ }^{27}$

Commercial leech collecting is documented for a few localities in Wales but in a strict sense, however, there is no unequivocal evidence that Welsh-collected leeches, as opposed to those transshipped via Wales, were ever sent to Dublin or any other part of Ireland.

\section{French Leeches}

The scarcity of leeches in Ireland as well as in Britain at the beginning of the nineteenth century was overcome with the defeat of Napoleon: 'Since the establishment of peace between this country and France, the importation of leeches has been so very considerable as to reduce the price of the English leech from $£ 7$ per hundred to $15 \mathrm{~s}$ '. ${ }^{28}$ This muchneeded, new source of leeches was newsworthy in October 1817: 'Forty thousand leeches were among the articles imported last week from France to Brighton: the whole were packed in clean straw, in which state it is said they will live two months without water'. ${ }^{29}$

There is compelling, yet circumstantial, reason to believe that some of these nominally French leeches found their way to Dublin via Holyhead in North Wales, the primary land route (coach and horses) between England and the Irish capital at that time. In this context, the vessel Henrietta was recorded carrying leeches from Holyhead to Dublin on 5 September 1817, and again on 5 June 1818; and the Dorset on 26 April $1818 .{ }^{30}$ Similarly, on 24 December 1819 the Dolphin imported seven jars of leeches from Bordeaux into the nearby port of Liverpool. ${ }^{31}$

The popular Irish novelist, Maria Edgeworth (1768-1849), of Edgeworthstown, County Longford, confirmed unequivocally that French leeches had been imported into Dublin by the summer of 1819 . On 7 July she wrote her aunt to express concern about her halfbrother: 'My Dear Aunt... Lovell is still in Dublin suffering from leech-bites; the last

${ }^{23}$ C. Butler, Butler's Medicine Chest Directory, and Family Catalogue of Drugs, Chemicals, etc, 3rd edn (Dublin: Messrs Butler, Medical Hall, 54 Lower Sackville St, 1832), 46.

${ }^{24}$ Charles Smith, The Ancient and Present State of the County and City of Cork Containing a Natural, Civil, Ecclesiastical, Historical, and Topographical Description Thereof (1750) (Cork: John Connor, 1815).

25 John Rutty, An Essay Towards A Natural History of the County of Dublin (Dublin: W. Sleater, 1772), 390.

${ }^{26}$ M. Donovan, 'Senegal leeches', Annals of Pharmacy and Materia Medica (Dublin: R. Graisberry), 1830, 243.

${ }^{27}$ M. Donovan, 'Letter From Mr Donovan Relative to a Proposal for the Propagation of Leeches in Ireland', Dublin Medical Press, 22 (September 26, 1849), 196.

${ }^{28}$ Morning Post (London), 11 February 1819.

${ }^{29}$ Bury and Norwich Post (Bury St Edmunds), 5 November 1817.

${ }^{30}$ Freeman's Journal (Dublin), 26 April 1817; 5 September 1817; 29 June 1818.

${ }^{31}$ Liverpool Mercury (Liverpool), 24 December 1819. 
importation of leeches from France were of a poisonous kind; a lady applied one to her gum for a slight toothache, and her head swelled...' 32

Intriguingly, this new type of 'French' leech was also associated with severe reactions in London at this time:

The puncture of the French leech is much larger, and deeper than that of the English leech, and this circumstance may account for the many cases of excessive loss of blood from the bites of leeches which have lately occurred in London. It is not uncommon for an obstinate erysipelatous inflammation to follow the application of the French leech, which in some instances has been so violent and extensive, as to endanger the lives of the patients. The French leech differs from the English leech, in the skin of the belly being of a yellowish hue, and being larger. It resembles the [non-bloodsucking] horse leech of this country. ${ }^{33}$

To judge from public advertisements in Ireland in the coming decades, the 'French leech' continued to be unpopular here, especially compared to those hawked as 'German'. Apart from a brief notice in Belfast in 1832, ${ }^{34}$ the only documented seller of French leeches in Ireland was John George Boileau of 26 Mary's Abbey (Capel St), Dublin. Boileau was a Huguenot descendant who advertised 'French and German' leeches from 1853 to 1859, never 'French' leeches alone. ${ }^{35}$

\section{Farming French Leeches in Ireland}

To counter the high price of imported leeches, Michael Donovan, foremost apothecary in Dublin's Apothecaries Hall, proposed in 1849 that a leech farm be established in Ireland. ${ }^{36}$ In 1852 such an enterprise was set up on Lord Desart's land in Callan, County Kilkenny, ${ }^{37}$ by a group of unnamed Frenchmen:

Lord Desart lately set a piece of marsh about forty acres, on his estate near Callan, to a company of Frenchmen, who immediately fenced it in; and having freely irrigated it, from an adjoining stream, proceeded to sow it down under a leech crop... The 'seed' if we may so express it, was contained in sacks - each sack holding 15,000 leeches, which were scattered from the hand, just as corn is sown. What will be said to this new race of Gallo Irish bloodsuckers. ${ }^{38}$

This facility was established by June 1852, and the abovementioned John George Boileau had just started selling (German) leeches to the public in April 1852, and French leeches the following January (1853). This tight chronology hints that Boileau was somehow linked to this French enterprise. Interestingly, another major leech importer in Dublin, Charles Keenan, filed for bankruptcy in March 1853 (but resumed trading the following year).

In circumspect, this Irish leech 'farm' may have served more usefully as holding ponds for imported leeches, rather than as a breeding facility per se. Such holding ponds were known to be employed by the largest leech importers in England, such as John Hudson in Hull, and Lesser Friedlander in London (who also had ponds in Hamburg). In any case no

\footnotetext{
${ }^{32}$ M. Edgeworth, A Memoir of Maria Edgeworth with A Selection From Her Letters, Edited by Her Children (London: Joseph Masters and Son, 1867), 2, 40.

33 Morning Post (London), 11 February 1819.

${ }^{34}$ Belfast Newsletter (Belfast), 3 April 1832, Thomas Mawhinny, Wholesale Leech Establishment, 4 North St, Belfast.

35 Nation (Dublin), 8 January 1853; Freeman's Journal (Dublin), 22 January 1859.

${ }^{36}$ Donovan, op. cit. (note 27), 196.

37 The estate of Lord Desart (variously spelled Dysert, Dysart) was located at Cuffesgrange near Callan (John Lucey, Environmental Protection Agency, Kilkenny, personal communication).

38 Nenagh Guardian (Nenagh), 19 June 1852.
} 
further information on this Irish leech farm was forthcoming as late as $1870^{39}$ and $1913,{ }^{40}$ but it can be assumed safely that it was unsuccessful for leech propagation.

\section{German Leeches: Not Always What They Seemed}

In Dublin, Belfast and elsewhere leech dealers hawked several colour 'brands' of leeches reflecting different geographical origins. 'Spotted leeches' (also variously advertised as speckled, black or grey leeches) are generally accepted, even today, as the darkly pigmented variety of medicinal leech collected from marshes and ponds in northern Europe, as far east as Prussia and Russia. ${ }^{41}$ Almost invariably they were shipped to the British Isles and other destinations from the port of Hamburg as 'German or Hamburg' leeches regardless of where they were actually collected. Leeches shipped from Hamburg, latterly foreshortened to the public as the brand 'Hambro leeches', ${ }^{42}$ were advertised to the Irish public until $1884,{ }^{43}$ but the specific brand Hambro leeches was still being used in Irish dispensaries as late as $1893 .{ }^{44}$

Another brand of medicinal leech, advertised as 'Green leeches' (also variously called officinal or officinal green leeches), had emerged on the Irish market at least by $1842,{ }^{45}$ from undetermined origins. In unpublished correspondence of 1855 Friedlander revealed that his 'green leeches' came from Hungary, via Paris. ${ }^{46}$ In 1868 one of the foremost leech importers in London, Fitch and Nottingham of St Peter Street, Hackney Road, promoted only two types of leeches on the contemporary market, namely 'Hambro speckled' and a much cheaper 'officinal green'. ${ }^{4}$

In 1893 the Hambro leech was at the centre of an industrial dispute in County Leitrim which revealed that doctors and local dealers were sometimes ill-informed with regard to the true origins of their leeches. In that year a doctor at the Mohill Dispensary made a formal complaint which went to tribunal. ${ }^{48} \mathrm{He}$ had specifically ordered English leeches but was supplied instead with foreign leeches for $6 \mathrm{~d}$ each. The procurement officer said in his defence that, 'some years ago, I supplied English leeches, because they were cheaper, and there were a great many complaints...'. He now supplied only 'Hambro' leeches which, he claimed, were reared at Marseille, France, and were superior. In point of fact, the socalled 'English' leeches did not come from England (by this time such a commercial brand did not exist), and the Marseille leeches had undoubtedly been imported into France. By

\footnotetext{
${ }^{39}$ P.L. Simmonds, 'The Trade in Leeches', Pharmaceutical Journal, Series 3, 1 (1870), 521-2.

${ }^{40}$ H. Whitehead, 'The Medical Leech in Ireland', The Irish Naturalist, 22 (1913), 19-20.

${ }^{41}$ H. Letheby, 'Classification and Structure of the Leech', Pharmaceutical Journal, 4 (1844), 252-7.

42 Medical Leech Museum Document C166, 'Importers of leeches, J Frankau \& Co, 41 Lime Street [London], which they receive twice each week from their ponds in Hambro', an advantage to the Trade which no other House can offer', from Pharmaceutical Journal, 1868, 29.

43 Belfast Newsletter (Belfast), 19 March 1884, Shaw \& Jameson, Wholesale Druggist, Belfast.

${ }^{44}$ Roscommon Herald (Roscommon), 14 January 1893.

45 Sir Patrick Dun's Hospital, Dublin, 8 November 1842: 'That Charles Keenan's proposal for the supply of Green leeches at 17/- for 100 be agreed', Royal College of Physicians of Ireland, PDH/1/2/1/2, 102 .

${ }^{46}$ Medical Leech Museum Document W1373, Letter of 9 April 1855 on letterhead of Marc Vial, Commerce Special de Sangsues, Rue Aubry-le-Boucher 33, Paris, addressed to Mr L. Friedlander, 3 Houndsditch, London, informing that Vial has a batch of fresh green Hungarian leeches, 4,000 of which would be shipped to Friedlander the following week.

${ }^{47}$ Medical Leech Museum Document C166, Fitch and Nottingham, 16 and 17 St Peters Street, Hackney Road, London,...Hambro' Speckled...10s per 100, and Officinal Green at 6s per 100, from Pharmaceutical Journal, 1868, 30.

${ }^{48}$ Roscommon Herald (Roscommon), 14 January 1893.
} 
1893 both England and France had long exhausted their commercial sources of domestic leeches, and were heavily involved in importing great quantities from elsewhere.

By way of summary, already by the 1840s a network of exporters and importers scrambled to get leeches into Ireland and other parts of western Europe from new sources, notably Baltic countries as far as Russia, Hungary and, outside the scope of this paper, from northwest Africa (Maghreb) and Turkey. Even some leeches from Senegal reached Dublin via France prior to $1830 .{ }^{49}$ The leech trade had become a complex international industry with transshipping intrigues of its own, and Ireland was very much a microcosm of these events.

\section{Lesser Friedlander}

In Belfast the brand 'German leeches' appeared in advertisements from $1832^{50}$ to $1869,{ }^{51}$ much earlier than in Dublin. A careful analysis of the records shows that these leeches did not come directly from Hamburg, but arrived circuitously via a major leech importer in London. This was Mr Lesser Friedlander of 3 Houndsditch, Aldgate, London, who imported leeches directly from Hamburg from 1834 until his death in 1879. A dominant figure in the British leech trade, Friedlander had set up a network of leech agencies in major cities throughout much of Britain; for example, Newcastle in 1849 (John and George Burrell), ${ }^{52}$ Liverpool in 1857 (Robert Broome) ${ }^{53}$ and Glasgow in 1862 (Alexander Friedlander, replacing H. Hart). ${ }^{54}$

In Belfast Friedlander appointed three agents in succession, identified as M. Beyfus (1839), Mrs M.A. Hoy (1846) and William Marshall (1860). For much of this period he sent weekly shipments of German leeches to these agents in turn, but the means of transport remains unclear. The agencies were for 'Belfast and the North of Ireland', there being no evidence Friedlander established an agency in Dublin. In fact, the large Dublin dealer, Boileau, advertised aggressively in Belfast in the Belfast Newsletter in late 1857 and early $1858 .{ }^{55}$ It is unlikely that Friedlander would have sanctioned one agent to compete against another.

\section{Beyfus}

Prior to 1837, M. Beyfus and L. Friedlander were business partners selling leeches and cigars from Haydon Square, London. In May of that year the partnership Friedlander \& Beyfus was dissolved by mutual consent. ${ }^{56}$ By May 1839 Beyfus was based at 19 Hercules Place, Belfast, and was newly appointed leech agent for Friedlander. Starting in December 1839 Beyfus was awarded a lucrative contract as sole supplier of leeches to Belfast General Hospital. In this capacity he supplied numerous leeches virtually every month until January 1845 when he was replaced in the hospital records by Friedlander himself. ${ }^{57}$

\footnotetext{
${ }^{49}$ Donovan, op. cit. (note 26), 243.

50 Belfast Newsletter (Belfast), 3 April 1832, Thomas Mawhinny, Wholesale Leech Establishment, 4 North St, Belfast.

51 Belfast Newsletter (Belfast), 21 January 1869, William Collins, Wholesale Leech Depot, 108 High St, Belfast.

52 Newcastle Cournant (Newcastle), 3 August 1849.

53 Liverpool Mercury (Liverpool), 26 June 1857.

54 Glasgow Herald (Glasgow), 13 June 1862.

55 Belfast Newsletter (Belfast), 21 November 1857 to 13 February 1858.

56 London Gazette (London), 9 May 1837; 12 May 1837; The Times (London), 10 May 1837.

57 PRONI, Board of Management, Minute Book, Belfast General Hospital, MIC 514/1/1/3 (1837-43); MIC 514/1/1/4 (1843-1847).
} 


\section{Hoy}

During 1839-42 Beyfus's address at 19 Hercules Place, Belfast, was a boarding house run by Mrs M.A. Hoy. ${ }^{58}$ In November 1846 Mrs Hoy, now at $171 / 2$ Hercules Place, was herself appointed Friedlander's leech agent. ${ }^{59}$ She continued trading in this capacity at this address until 1860 when she was replaced as Friedlander's agent by William Marshall. ${ }^{60}$ However, Mrs Hoy continued importing leeches at 17 1/2 Hercules Place until $1866{ }^{61}$ Thereafter, her immediate neighbour Miss Letitia Russell, erstwhile straw bonnet maker, imported leeches at 25 Hercules Place from 1870 until $1880 .^{62}$

\section{Marshall}

The Marshall family were prominent chemists and druggists in central Belfast during the first half of the nineteenth century. ${ }^{63}$ Andrew Marshall, variously labelled surgeon, apothecary, chemist, druggist and even midwife, operated at various addresses on High Street from 1806, but finally settled at 100 High Street from 1824 to $1832 .{ }^{64}$ There is no record of his selling leeches but as surgeon-apothecary he undoubtedly applied them to customers for a charge.

At 100 High Street, by now known as Belfast Medical Hall (opposite St George's Church), William Marshall sold leeches from 1835 until the 1860s. He advertised his 'German leeches' in the Belfast Newsletter in 1835 and again in 1836-8. In 1839 he occasionally supplied leeches and other medicines to Belfast General Hospital. He ceased selling leeches to them from that year when the aforementioned Beyfus entered the picture, but Marshall continued supplying other medicines to the hospital until at least 1845 . Although William Marshall \& Co was listed as selling leeches in city directories up to 1844 , one senses a rather low-keyed marketing effort with respect to leeches, and certainly Marshall was not the dominant player in this competitive market at this time.

In October 1846 another Marshall, James D. Marshall of 8 High Street, announced that he had 'made arrangements with one of the largest continental importers of leeches in London... ${ }^{65}$ It is not clear whether this London importer to which he refers was L. Friedlander, but it may be relevant that the latter appointed Mrs Hoy as his agent only one month later. In any case James Marshall placed no further leech advertisements.

At the beginning of 1858 William Marshall abruptly embarked upon an aggressive marketing campaign to sell leeches. From 8 February until 6 May he advertised in Belfast Newsletter literally every day! This was in apparent response to the Dublin leech dealer, John George Boileau, who ran an aggressive campaign in the same newspaper from 21 November 1857 until 13 February 1858.

\footnotetext{
58 Martin's Belfast Directory (Belfast: Matthew Martin, 1839), 72; loc. cit. (Belfast: Matthew Martin, 1841-2), 150.

${ }^{59}$ Belfast Newsletter (Belfast), 3 November 1846.

${ }^{60}$ Belfast Newsletter (Belfast), 17 January 1860.

${ }^{61}$ Belfast and Province of Ulster Directory (Belfast: James Henderson, 1866), 66.

${ }^{62}$ Belfast and Province of Ulster Directory (Belfast: James Henderson, 1870), 301, 654; loc. cit. (Belfast: James Henderson, 1880), 511.

63 By 1870, 100 High Street was listed as 'vacant' in the Belfast Directory (Belfast: James Henderson).

${ }^{64}$ Belfast Traders' Directory (Belfast: Smyth and Lyons, 1806); Belfast/Ulster Street Directory (Belfast: Smyth and Lyons, 1807); Belfast Directory (Belfast: Smyth and Lyons, 1808); Bradshaw's General and Commercial Directory (Belfast: Thomas Bradshaw, 1819), 47; Pigot's Directory (Belfast: James Pigot, 1824); Belfast Directory (Belfast: James Pigot, 1831-32), 34.

${ }^{65}$ Belfast Newsletter (Belfast), 6 October 1848.
} 
In January 1860 William Marshall was appointed agent for L. Friedlander, replacing Mrs Hoy:

\author{
LEECHES! LEECHES! LEECHES! \\ L. FRIEDLANDER of No. 3, Houndsditch, London, \\ begs to inform...that he has withdrawn his \\ Agency from Mrs M.A. Hoy of $171 / 2$ Hercules Place, \\ Belfast, who is no longer authorised to sell on his account. \\ L.F. Begs [to thank for patronage] and continuance through \\ his present agents, Messrs W. Marshall \& Co, wholesale chemists \\ and druggists, 100 High St, Belfast, who will always have on \\ hand a fresh supply of the FINEST HEALTHY SPOTTED and GREEN LEECHES, \\ direct from his own ponds, and who will furnish them at the \\ lowest current London Wholesale Market Prices, so as to defy \\ all competition. ${ }^{66}$
}

\title{
John George Boileau
}

The specific availability of 'German leeches' rather than just 'leeches' was proclaimed in newspaper ads in Dublin between 1852 and 1859. ${ }^{67}$ We know from another source, however, that German leeches were being imported into Dublin prior to 1849 when the aforementioned apothecary Donovan wrote that Germany 'still affords us ample supplies'. 68

In 1857 John George Boileau placed a revealing notice in the Freeman's Journal, Dublin's then foremost newspaper. In this ad he stated unequivocally that he received a 'regular weekly supply of leeches from Hamburgh'. ${ }^{69}$ It is probable that he imported these by ship directly from Hamburg, a major centre of the leech trade, but it is possible that he acquired them indirectly via leech importers in England, as shown below for some leech dealers in Belfast.

Nonetheless, ships registered in Dublin were indeed heavily involved elsewhere in importing leeches from Hamburg, at least in the 1830s and 1840s. From 1835 until at least 1842 four ships, consistently recorded as being from Dublin, transported a significant number of leeches from Hamburg into the port of Hull. These ships were the William IV, Lee, Severn and Tiger, respectively. Interestingly, the first two were recorded as from Liverpool in 1834, but thereafter from Dublin. One particular ship's captain, identified only as 'Capt Knocker', was noteworthy in that he commanded three of the ships successively: William IV (to May 1834, Liverpool), Severn (June 1835-December 1837) and Tiger (August 1838 to at least November 1842). During the period 1835-42, these four ships transported more than one-quarter of the 510 leech 'baskets' imported into Hull from Hamburg, amounting to many thousands of leeches: Tiger (seventy-three leech 'baskets'), Severn (forty-two), William IV (nine) and Lee (nine), respectively. During the week of 13 November 1835 three Dublin registered ships were the only vessels which managed to import leeches at all. ${ }^{70}$

By October 1857 Boileau was receiving two shipments of German leeches each week, ${ }^{71}$ but on 15 December he abruptly notified his customers of problems:

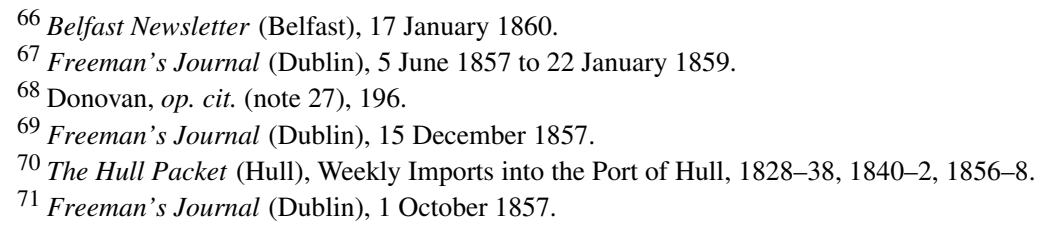


Leeches. We have experienced some difficulty in receiving our regular weekly supply of Leeches from Hamburgh, owing to the disturbed state of commercial affairs in that city; and having detected the introduction of a very inferior description into the market, we deem it prudent to bring this matter under the notice of the Medical Profession, assuring them of the quality we are selling being the very finest German Pond Speckled. ${ }^{72}$

Boileau was referring to the global financial crisis of 1857 following the end of the Crimean War. This upheaval in getting leeches from Hamburg was a temporary interruption in that Boileau resumed selling German leeches the following March (1858). In December 1857 Boileau also accused a competitor in Dublin of recently importing 'inferior' leeches from some undetermined source. Naturally, he denigrated his competitor's stock in favour of his own brand of 'German leeches', but one suspects more as a businessman than as a medical practitioner. Interestingly, Boileau placed his last leech ad the following year (January 1859).

\section{Leech Entrepreneurs: Local Dealers}

An array of dealers sold leeches to the public or to local dispensaries throughout Ireland. As a rule these entrepreneurs placed prominent advertisements in newspapers, directories and medical publications. From the earliest known such advertisement in $1820^{73}$ to the last one in $1884^{74}$ more than 350 such notices were placed by more than fifty dealers in Dublin, Belfast and other towns throughout Ireland.

The most enduring leech importer and dealer in Dublin was Charles Keenan. He was located initially at 53 Henry Street (trading from this address 1832-41), and later at nearby 22-4 Mary Street (1843-84) in closer vicinity of Apothecaries' Hall. Furthermore, Keenan's widow carried on the leech trade at 24 Mary Street until 1888. Interestingly, Keenan may have assumed the pre-existing trade of J. Lynham who was recorded in 1832 as 'importer and wholesaler of leeches' virtually next door at $471 / 2$ Henry Street. $^{75}$

For over fifty years Keenan was one of Dublin's pre-eminent leech importers, and from at least 1875 he was the only importer of record in Dublin. He never advertised his leeches to the public, as did most of his competitors. Instead, his customers were primarily local hospitals with whom he won competitive contracts. These included Townsend Street Cholera Hospital (1832), Cork Street Fever Hospital (1841) and Sir Patrick Dun's Hospital (1842). ${ }^{76}$ The source of Keenan's leeches is not known, but in 1842 he contracted to furnish the latter hospital with 'Green leeches' (ie. not originating from northern Europe, as discussed below).

The earliest known specialist dealer of leeches was Price's Medical Repository of Dublin which announced in 1825, 'Just Imported, a large supply of fine healthy Leeches'. ${ }^{7}$ While much of the leech retail trade was vested in a few established dealers, a number of enterprising individuals sold leeches alongside other chosen trades. These tradesmen were remarkably diverse; for example, cabinet maker (Champion), straw hat maker and milliner (Russell), surgical instrument retailer (Collins), postmaster, bookseller, and dealer

\footnotetext{
72 Freeman's Journal (Dublin), 15 December 1857.

73 Freeman's Journal (Dublin), 7 February 1820, Charles Butler, 34 Lower Sackville St, Dublin.

${ }^{74}$ Belfast Newsletter (Belfast), 19 March 1884, Shaw \& Jameson, 88 1/2 Ann St, Belfast.

75 Wilson's Dublin City Directory (Dublin: Peter Wilson, 1932), 101; Interestingly, a Thomas Lynham was recorded selling leeches at 47 1/2 Henry Street in 1836. Third Report from the Select Committee on Fictitious Votes, Ireland (London: House of Commons, 5 July 1837), 266.

${ }^{76}$ Receipt and Expenditure, op. cit. (note 8); Charitable Institutions (Dublin), Report of the Commissioners (London: House of Commons, 16 June 1842), 114; Royal College of Physicians of Ireland, PDH/1/2/1/2, 102.

${ }^{77}$ Freeman's Journal (Dublin), 26 July 1825.
} 
in wines and cigars (Hogan), government contractor (Shannon), fruit dealer (Isaac), and spice, colour and oil dealer (Walkington). Sometimes wives took over from their husbands; for example, Charles Keenan and widow in Dublin, John and Elizabeth O'Neill in Dublin, and $\mathrm{Mr}$ and Mrs P.J. English in Mullingar. More than one leech dealer went bankrupt; for example, Lyon Isaac in $1841,{ }^{78}$ and Charles Keenan in $1853 .^{79}$

Leech dealers catering to local dispensaries and hospitals typically competed on the basis of price because of a widespread policy of public tendering. ${ }^{80}$ In Belfast, successive agents of the London-based leech importer L. Friedlander repeatedly advertised that they furnish their leeches 'at the lowest current London wholesale prices, so as to defy all competition'. His agent M. Beyfus stated this price to be 19s per hundred leeches in $1839 .{ }^{81}$ Interestingly, however, in 1841 and 1842, Charles Keenan had won contracts in Dublin to supply leeches to the Cork Street Fever Hospital and Sir Patrick Dun's Hospital for only $16 \mathrm{~s}$ and $17 \mathrm{~s}$ per hundred, respectively. ${ }^{82}$ For whatever reason, leeches did seem to be consistently cheaper in Dublin than in Belfast.

\section{A Case Study: High Street Chemist in Nineteenth-Century Belfast}

In the nineteenth century chemist shops throughout the world regularly sold leeches to their clientele (see figure 1), but the commercial intricacies of this trade has been elusive. Towards this end, the Public Records Office of Northern Ireland (PRONI) holds the sales ledgers of Grattan \& Co, Belfast - all 189 volumes of them from 1827 until 1959. These ledgers are unique in that they comprise a daily record of their leech sales over a period of years, including the identity of the leech customers, as well as when, how many and at what price leeches were purchased. Fortunately, the ledgers also reveal that Grattan \& Co received periodic shipments of leeches from a single supplier in London. ${ }^{83}$ This is the first time that financial data on retail and wholesale aspects of the leech trade by a major chemist of the nineteenth century has ever come to light.

Grattan \& Co was located in the centre of Belfast at Medical Hall, 12 Corn Market Street, where it became one the largest and most enduring chemists in Ireland. For the purposes of this paper their sales ledgers were examined each day for a forty-two-month period from December 1829 until February 1834 (excepting the period June-November 1832 due to a missing ledger). ${ }^{84}$ An unexpected finding is that Grattan \& Co sold its leeches primarily to the upper echelons of Belfast society, well outside the domain of the poor. Although they sold well over 1,000 leeches a year, the trade appeared to be hardly profitable in that the cost of their leech stock was comparably high.

During the forty-two-month period Grattan \& Co sold a total of 3,649 leeches to 127 retail (and two wholesale) customers who together placed a total of 262 separate orders for leeches. The most common number (mode) of leeches purchased per order was six $(24.4 \%$ of all orders), followed by twelve (21.0\%), two (9.5\%) and eight (7.3\%; Statistically, the mean for each retail order was 8.8 leeches, and the median was 12 leeches). The range

\footnotetext{
78 Freeman's Journal (Dublin), 30 October 1841, Insolvent Debtor, Lyon Isaac, Cutpurse Row, Dealer in fruit and leeches.

79 Freeman's Journal (Dublin), 3 March 1853, Insolvent Debtor, Charles Keenan, late of Emerald St, Sheriff St, Dealer in leeches.

${ }^{80}$ Freeman's Journal (Dublin), 15 October 1852.

81 Belfast Newsletter (Belfast), 24 September 1839.

${ }^{82}$ Charitable Institutions, op. cit. (note 76); Royal College of Physicians of Ireland, PDH/1/2/1/2, 101, 102.

83 PRONI, D1072.

${ }^{84}$ PRONI, D1072/1/4-8, 10-11.
} 


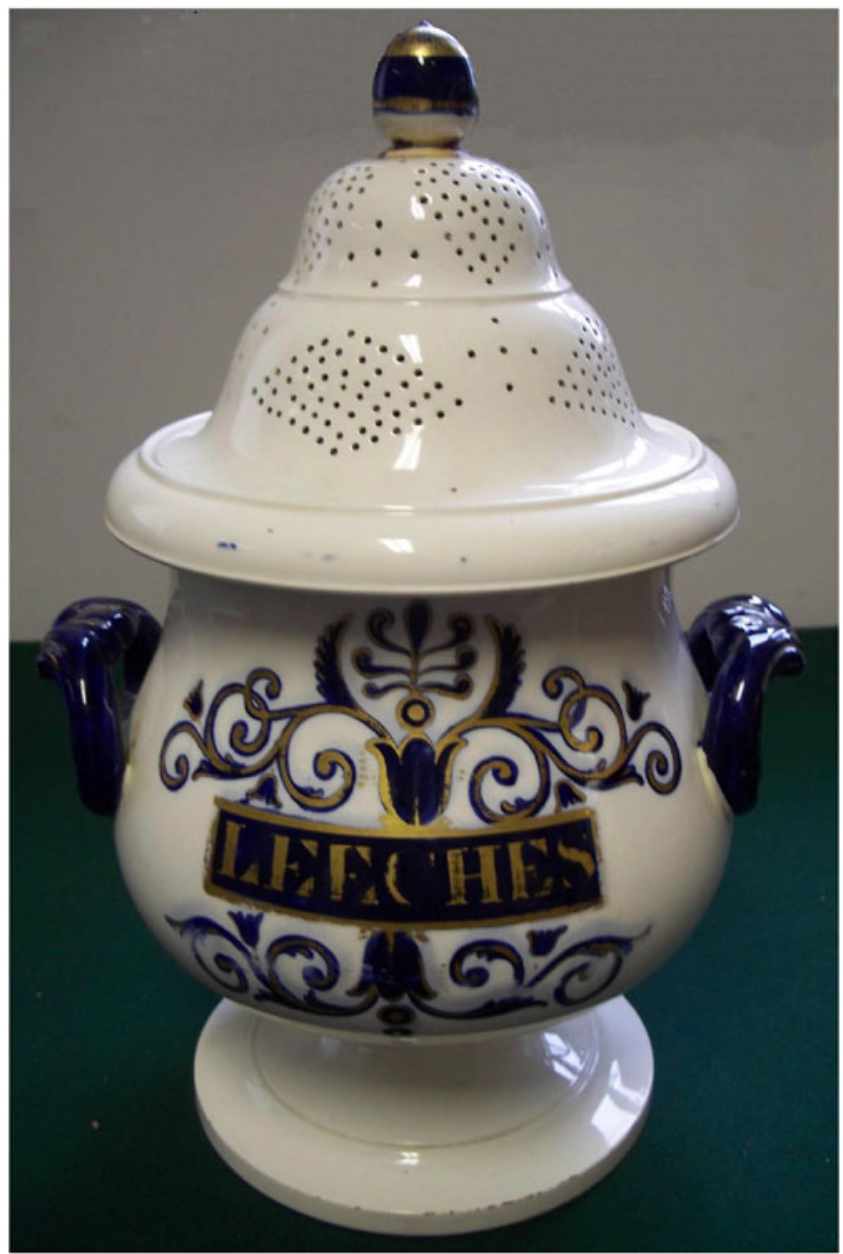

Figure 1: Irish leech jar. This unmarked Staffordshire leech jar was presented to the Royal College of Surgeons in Ireland by the family of Widdess who still have a chemist shop in Limerick City. Author's photo, courtesy of the Royal College of Surgeons in Ireland, Dublin.

varied from one (1.1\% of all orders) to four dozen $(0.4 \%)$ leeches in a single order. The overwhelming majority of customers ordered leeches only once $(67.4 \%)$, followed by those who ordered twice $(17.1 \%)$, three times $(7.0 \%)$ and four times $(4.7 \%)$, respectively. Only a small minority of customers ordered eight or more times $(4.0 \%)$.

The ledger entries themselves are informative of Grattan \& Co's ambiguous attitude toward the leech as a product in that approximately one in seven entries (13\%) was recorded in apothecary's Latin. For example, an order for twelve leeches was sometimes entered as 'hirudines duodecem' or 'hirudines xii'. Such Latinised entries occurred in spurts, possibly implying individual pedantry.

The remarkable feature of the customer list is that, as a rule, they represented the upper end of society; that is, nobility, gentry, clerics and merchants. The clients who purchased the most leeches were veritable pillars of society. For example, George Black, Esq, Gentleman, of 4 Donegal Sq-West and Strandmills, placed 19 orders, totalling 180 
leeches. Sir Robert Bateson, MP, DL, of Belvoir Park, and Lady Bateson, placed 14 orders, totalling 143 leeches. Henry Lyons, Esq., of the Lodge and Old Park, placed 10 orders, totalling 88 leeches. Richard Dobbs, Esq., JP and Barrister, of 5 Donegal Sq-West and Dobbs Castle (Carrickfergus), placed four orders, totalling 30 leeches. These leeches were probably donated to dispensaries, hospitals and other local charities patronised by each of these wealthy individuals. ${ }^{85}$

Unexpectedly few leeches were sold directly to medical practitioners. Only seven physicians and four surgeons purchased leeches, and then only a few at a time. Ship captains occasionally stocked a variety of medicines from Grattan \& Co, and of these five captains purchased relatively small numbers of leeches.

The vast majority of customers lived in central Belfast, but some orders came from clients living some distance away, including Carrickfergus (three customers), Hollywood (three), Lisburn (three), Ballycraigy (one), Banbridge (one), Coleraine (one), Dromara (one), Dunmurry (one), and Lurgan (one). Mostly, leeches were acquired at Grattan \& Co's Corn Market address, but on five occasions they were shipped to the final destination, presumably by carriage, for which a 'bookage' fee of $2 \mathrm{~d}$ was added.

In a typical advertisement for Grattan \& Co's many medical products, the following notice appeared at the end of each ad: 'All the above [products] may be had of the same quality, and at the same prices, as in Belfast, at Mr Thomas Grattan's Medical Hall, 20 Scotch St, Armagh; and of Mr George Young, Surgeon and Licentiate Apothecary, Downpatrick' ${ }^{86}$ These were the only two individuals who regularly ordered four dozen or more leeches at a time (ie. wholesale).

Surgeon George Young placed 29 orders, totalling a remarkable 1,406 leeches, with the frequency of his orders declining toward the end of the forty-two-month period. Thomas Grattan entered the market later, commencing 17 April 1833, but during an intense tenmonth period he placed eight orders, totalling 322 leeches. Surgeon Young typically purchased his leeches at a discounted price of $2 \mathrm{~d}$ each, but Thomas Grattan was especially favoured at only $1 \mathrm{~d}$ per leech.

The majority of leeches sold for $4 \mathrm{~d}$ each. However, prices charged to customers were seemingly subject to much discretion, conceivably attributable to size or health of the leeches or, one suspects, to less than rigorous financial control. For example, on different days $1 \mathrm{~s}$ purchased two, three, four or even six leeches. Similarly, 2 s variously purchased three, four, six or eight leeches. Having said that, however, there was a definite, if poorly observed, pricing structure: one to two leeches sold for $5 \mathrm{~d}$ each; three to twelve leeches for 4d each; and twenty-four for 3-4d each.

Over the forty-two-month period, total sales income from the sale of 3,649 leeches was $£ 48 / 18 / 7$, excluding accessories like carrying containers (bottles). On an annualised basis this was $£ 13 / 2 / 4$ income per year, based on an average annual sale of 1,043 leeches. Over $50 \%$ of gross income came from orders of -one to twelve leeches, and a further $25 \%$ was from wholesale orders of forty-eight to fifty leeches. Only a minority of income $(6.3 \%)$ came from the many small orders of one to four leeches $(22.1 \%$ of all orders).

The overwhelming majority of orders involved the additional purchase of a 'bottle' for carrying leeches. The typical charge for such bottles was $2 \mathrm{~d}$ per order. On four occasions, in addition to leeches, a surgeon also purchased a specialised 'leech applyer' or 'leech

\footnotetext{
${ }^{85}$ By way of example of local medical philanthropy, in 1839 Henry Lyons left an annual legacy of $£ 30$ to Belfast Fever Hospital, Return of the Commissioners of Charitable Donations and Bequests (Ireland), since 1830 (London: House of Commons, 1844), 124.

${ }^{86}$ Matier's Belfast Directory (Belfast: William T. Matier, 1835-6), xi.
} 


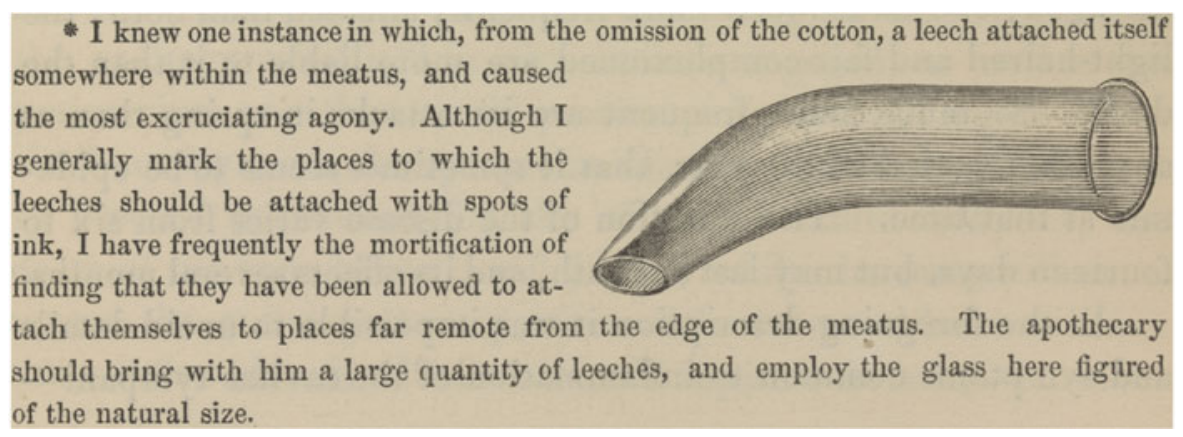

Figure 2: For the treatment of ear inflammation Dublin surgeon W.R. Wilde, father of Oscar Wilde, pioneered the use of leeches in his medical text Aural Surgery (1853, 93-5): 'Leeches are, however, the effectual means of abstracting blood and relieving pain in all such cases.... They must be attached with a small bevil-mouthed leech-glass immediately around and within the edge of the external meatus.... From four to six leeches may be readily attached round the meatus.... The external meatus should first be filled with a bit of cotton wool, to a level with the external aperture, not so much for the purpose of preventing the leeches going in too far, as to exclude the blood'. Courtesy: Wellcome Library, London.

tube' (see figure 2) which incurred a charge of 1s 8d, and on two occasions a 'leech glass' was purchased for $1 \mathrm{~s} 0 \mathrm{~d}$. On one occasion, in addition to a 'leech applyer', a surgeon also purchased a 'shaving bowl' [barber's bowl] at $4 \mathrm{~s} 6 \mathrm{~d}$, the presumption being that it served as a bleeding bowl. ${ }^{87}$ The only other accessory occasionally linked to leech purchases was a wad of 'lint' at $2 \mathrm{~d}$. Grattan \& Co retained an associate apothecary certified to apply leeches, typically in a customer's home. The records indicate this service occurred on only five occasions at a relatively high fixed fee of $5 \mathrm{~s}$ each time.

Grattan \& Co's sole supplier of leeches was the London office of John Hudson \& Son, Leech Importer, of Hull and London. In 1822 Hudson started importing leeches from Hamburg into Hull where he had his own leech holding ponds. Soon he was probably the largest leech importer in England at the time:

From the 1st September to the 6th October [1825], Mr Hudson, of Hull, has imported the extraordinary number of one million three hundred sixty-five thousand foreign leeches! Sufficient I should think to bleed John Bull to death. ${ }^{88}$

By 1832 Hudson also had a base in London (26 Hosier Lane) ${ }^{89}$ from which Grattan \& Co's leeches would have been despatched approximately twice a year. Each shipment varied from 1,000 to 2,000 leeches, the cost varying from 70-130s per thousand, plus the holding container ('cask'; typically 1s extra) and, later in some circumstances, customs duty of 0 s $4 \mathrm{~d}$ per leech packet. ${ }^{90}$

With respect to their acquisition of leech stock, calculations are based on the only two years, 1830-1, in which leech purchases were clearly indicated in the ledgers (see

${ }^{87}$ PRONI, D1072/1/6, 28 September 1831. This is rare documentation that barber bowls, as compared to bleeding bowls, may have been associated with bloodletting in the nineteenth century.

${ }^{88}$ Hampshire Telegraph (Southampton), 31 October 1825.

${ }^{89}$ Pigot's National and Provincial Commercial Directory (London: James Pigot), 1832-4.

${ }^{90}$ Report of the Commissioners on Local Charges upon Shipping, Ireland. Customs Port of Londonderry. Description of dues and charges levied by the Londonderry Port and Harbour Commissions, 2 (1855), Duties on Imports and Exports, 51 (Leeches). 


\begin{tabular}{|c|c|c|c|c|c|}
\hline Date & Leeches & $\begin{array}{l}\text { Leech cost, } \\
\text { total } \\
\text { (shillings) }\end{array}$ & $\begin{array}{l}\text { Leech cost, } \\
\text { per } 100 \\
\text { (shillings) }\end{array}$ & $\begin{array}{l}\text { Cask cost } \\
\text { (shillings) }\end{array}$ & $\begin{array}{c}\text { Cost, } \\
\text { per leech } \\
\text { (pence) }\end{array}$ \\
\hline 16 March 1830 & 1,000 & $120 / 0$ & $12 / 0$ & $1 / 0$ & 1.452 \\
\hline 13 May 1830 & 2,000 & $140 / 0$ & $7 / 0$ & $1 / 6$ & 0.849 \\
\hline 11 June 1831 & 1,500 & $112 / 6$ & $7 / 6$ & $1 / 6$ & 0.912 \\
\hline 3 September 1831 & 1,000 & $130 / 0$ & $13 / 0$ & $0 / 0$ & 1.5 \\
\hline
\end{tabular}

table 1). ${ }^{91}$ Annualised, a total of $£ 12 / 13 / 3$ purchased an average of 2,750 leeches per year. Therefore each purchased leech cost $1.11 \mathrm{~d}$ each. However, as shown above, only 1,043 leeches were sold in each of these two years, resulting in annual income of $£ 13 / 2 / 4$, a net profit of only $£ 0 / 9 / 1$ (3.5\%). In other words, against expectations, Grattan \& Co was barely covering the costs of selling leeches in these two years. A significant factor is that they sold leeches near or below cost to their agents Surgeon Young ( $2 \mathrm{~d}$ per leech) and Thomas Grattan (1d) who together comprised one-quarter of their leech sales. The cost for each leech sold was actually 2.93 pence. This underselling again implies a lack of adequate financial control.

The annual discrepancy in 1830 and in 1831 between the leeches purchased each year $(2,750)$, and those sold $(1,043)$ can be attributed to several factors. As with any perishable commodity, death and sickness undoubtedly played a role as suggested by the observation that over six dozen leeches were returned during the full forty-two-month period under review. More likely, however, Grattan \& Co simply purchased more leeches than they were able to sell. This explains why they advertised their leeches in the Belfast Newsletter in 1830 (5 March, 6 July and 7 September) and, with a sense of urgency, in early 1831 (4, 11, 18 and 25 January). Apparently they never placed any more leech ads in the following years. A cursory glance at their 1843 sales ledger ${ }^{92}$ suggested that, by then, they were no longer selling leeches. However, Grattan \& Co continued to supply non-leech medicines to Belfast General Hospital for many years thereafter. ${ }^{93}$

\section{The Leeching of Irish Hospitals and Obsolescence}

\section{Sir Patrick Dun's Hospital, Dublin}

From the outset Sir Patrick Dun's Hospital (c.1800-1986) on Grand Canal Street served primarily as a university teaching hospital and, arguably, was at the forefront of medical practice. ${ }^{94}$ In this context the extent to which leeches were prescribed by the medical establishment in this hospital reflected contemporary attitudes to leech therapy in midnineteenth century Dublin. Fortunately, the Royal College of Physicians of Ireland holds

\footnotetext{
${ }^{91}$ Leech purchases were not observed in the ledgers during January-May 1832 (PRONI, D1072/1/8) or in 1833 (PRONI, D1072/1/10-11). The ledger June-December 1832 (PRONI, D1072/1/9) was missing.

92 PRONI, D1072/1/29.

93 PRONI, MIC 514/1/1/3.

94 Fleetwood, op. cit. (note 3), 207, 214-15.
} 
extensive archives on this hospital. ${ }^{95}$ Specifically, the minute books of this period disclose unequivocally that leeches were very much in favour at this hospital and constituted a remarkably significant component of the hospital's overall medicines budget for a number of years.

In 1837 the hospital spent $£ 42 / 17 / 6$ on leeches, and an additional $£ 122 / 11 / 6$ on other medicines/drugs - that is, leeches - constituted $35.0 \%$ of the non-leech medical budget. Assuming that the leeches cost $17 \mathrm{~s}$ per $100,{ }^{96}$ the hospital purchased 5,044 leeches in 1837, an average of 420 each month. Considering that the average number of patients treated each month in 1837 was disclosed in the ledgers to be 1,254, it can be inferred that leeches were applied, on average, to one in every three patients. The hospital apothecary, identified as a Mr Lloyd, would have been charged amongst his duties with applying, or supervising the application of, an average of fourteen leeches each day throughout the year. Admittedly, the year 1837 may have been exceptional in this regard, possibly due to an epidemic which would explain an abrupt near doubling of patient numbers in June which continued at this high level through November. Nonetheless, fifteen years later expenditure for leeches continued to be extensive: $£ 10 / 4 / 6$ for 1,203 leeches (1851), $£ 14 / 19 / 3$ for 1,760 leeches (1852), and $£ 9 / 15 / 0$ for 1,147 leeches (1853). They still constituted a significant proportion of each year's expenditure for non-leech medicines, namely $25.6 \%$ (1851), $29.3 \%$ (1852) and $13.0 \%$ (1853), respectively. ${ }^{97}$

\section{Belfast General Hospital}

By way of comparison, the leading hospital in mid-nineteenth century Belfast was the imposing General Hospital on Frederick Street, later to become today's Royal Victoria Hospital on Grosvenor Road. ${ }^{98}$ Its minute books from 1837 to 1846 reveal in monthly detail that leeches were an increasingly expensive component of the total medical budget throughout this period. ${ }^{99}$ From 1837 until June 1839 the total expenditures each month for all medicines were entered together as a single sum under the category 'drugs' (or variously 'medicines'). No doubt leeches were being purchased during this period but they were not itemised separately. From June until December 1839 the category had changed to 'drugs and leeches', but it was not broken down further as to how much was spent specifically on leeches. However, the names of individual suppliers revealed that the hospital had three different leech suppliers during this period, each of which also supplied drugs/medicines. These were William Marshall \& Co (first mentioned as supplying leeches to this hospital in June 1839), John McAdam (August 1839) and Charles McAlister (September 1839).

From December 1839 'leeches' were itemised separately from the drugs/medicines category, undoubtedly indicative of the increased proportion of the budget allocated to them. During the five-year period 1841-5 the total annual expenditure for leeches increased markedly each successive year: £7/14/9 (1841), £11/3/11 (1842), £13/4/3 (1843), £20/18/0 (1844) and £27/10/9 (1845). Furthermore, during this same five-year period leeches increased disproportionately in relation to the total annual drugs/medicines

\footnotetext{
95 Harriet Wheelock, Sir Patrick Dun's Hospital Collection, Royal College of Physicians of Ireland, Heritage Centre, 2010, 1-167.

96 In October 1842 Sir Patrick Dun's Hospital advertised for competitive bids to supply leeches. The following month the hospital accepted 'Charles Keenan's proposal for the supply of Green Leeches at 17/0 per 100', Royal College of Physicians of Ireland, PDH/1/2/1/2, 101, 102.

${ }^{97}$ Royal College of Physicians of Ireland, PDH/1/2/1/2, 311, 348, 354; PDH/1/2/1/3, 5.

98 Allison, op. cit. (note 3); Craig, op. cit. (note 3).

${ }^{99}$ PRONI, MIC 514/1/1/3; MIC 514/1/1/4.
} 
budget (exclusive of leeches), from $4.5 \%$ (1841) to $12.0 \%$ (1845). In other words, leeches were quickly becoming a major expenditure for this hospital.

December 1839 was also remarkable in that, for the first time, leeches were supplied exclusively by a specialist leech dealer, namely M. Beyfus mentioned above. He supplied leeches virtually every month from December 1839 until January 1845 . We know from data discussed elsewhere that Beyfus acquired his leeches from Mr Lesser Friedlander of London who in turn had imported them from Hamburg. Interestingly, from February 1845 until April 1846, Beyfus was replaced in the ledger entries by Friedlander himself, for reasons which are not clear. Thereafter, these ledgers ceased to record the medical budget.

In any case, from December 1839 until April 1846 Beyfus/Friedlander was paid the remarkable sum of $£ 101 / 7 / 10$ for a total of 10,673 leeches. In 1845 alone the hospital purchased a total of 3,900 leeches; that is, 325 per month. These calculations are based on the hospital's paying the competitive rate of 19s per 100 leeches, the price Beyfus had advertised in September 1839. ${ }^{100}$ There is evidence, however, that the price fluctuated somewhat, from 21s 10d per 100 (June 1840), 26s 6d per 100 (1850) and 22s 1d per 100 (1863). ${ }^{101}$

\section{Poor Law Union Dispensaries}

While some large urban hospitals consumed considerable numbers of leeches, a national network of dispensaries and hospitals for the poor, taken together, contributed significantly to the overall consumption of leeches in Ireland. The Irish Poor Law Act of 1838 divided Ireland into 163 Poor Law Unions (geographic areas) for the 'relief of the destitute poor'. Each union had one or more workhouses and an associated dispensary or hospital for the sick poor. ${ }^{102}$ Leeches were applied to the poor in these medical facilities, but not to the same extent as with wealthier patients, in part because of cost of the leeches, ${ }^{103}$ and in part because of increased demands on medical staff. ${ }^{104}$

Nonetheless, expenditure for leeches in these Poor Law dispensaries was a significant part of the annual expenditure for each union. By way of example, annual leech expenditures for three dispensaries within County Tipperary were $£ 1 / 14 / 0$ (1839), £3/18/6 (1850) and $£ 1 / 1 / 0$ (1851), which constituted $4.0 \%, 13.0 \%$ and $3.2 \%$ of the annual (nonleech) medicines budget, respectively. ${ }^{105}$ In 1848 the Ballymena Union infirmary used about 50 leeches each month. ${ }^{106}$ In 1863 the Cork Poor Law Hospital alone used about two dozen leeches per week (ie. 1,248 leeches per year). ${ }^{107}$

Tendering for leeches was particularly characteristic of dispensaries in each of 163 unions in the second half of the nineteenth century. Until May 1859 the winning

\footnotetext{
100 Belfast Newsletter (Belfast), 24 September 1839.

101 PRONI, MIC 514/1/1/3, £1/7/3 for 125 leeches (June 1840); Allison, op. cit. (note 3), £2/13/0 for 200 leeches (1850), 39; £2/15/2 for 250 (1863), 210.

102 For example, B. MacDonald, 'A Time of Desolation: Clones Poor Law Union, 1845-50', Clogher Record, 17, 1 (2000), 1-146; C. O’Mahony, Cork's Poor Law Palace: Workhouse Life 1838-90 (Cork: Rosmathun Press, 2005), 223.

103 Freeman's Journal (Dublin), 22 May 1812.

104 Wilde, op. cit. (note 10), 17-43.

105 County Tipperary Dispensaries: Nenagh Guardian, 8 January 1840 (Nenagh Dispensary); 24 July 1850 (Roscrea Dispensary); 12 March 1851 (Thurles Dispensary).

106 PRONI, BG/4/A/1-2, Ballymena Union, Minute Book: 50 leeches ordered in 1848 on 8 January, 1 April, 13 May, 29 July, 16 September (along with 'two leech pots'), 2 December; 26 May (1849).

107 Cork Examiner (Cork), 20, 28 May 1863.
} 
leech dealer could be located virtually anywhere in Ireland, but in too many cases the dispensaries experienced delays and leech deaths attributable to the distance from the specialist leech dealer. Therefore on the basis of economy the Board of Guardians recommended getting leeches from a local apothecary or druggist whenever possible. $^{108}$

The invited price was initially to be quoted per 100 leeches, but by the 1880 s the price was per dozen. In 1889 Mrs English was awarded the winning bid of 6s per 12 leeches at the Mullingar Workhouse. ${ }^{109}$ This is equivalent to 50s per 100 leeches, an inflation of over $250 \%$ in fifty years. By the 1890 s it appears that one dealer could supply a number of workhouses. For example, P.N. White, who supplied the dispensary at Mohill, County Leitrim, in 1893, had 'dealings with somewhat about 60 Union medical officers' 110

\section{Demise of the Irish Leech Trade}

The decline in the use of leeches was not precipitous in Ireland. In fact, they were still being used to a limited extent well into the twentieth century, until at least 1905 at the Royal Hospital for Incurables, Donnybrook, Dublin, ${ }^{111}$ and 1915 at the Westmoreland Lock Hospital, Townsend Street, Dublin. ${ }^{112}$

The reasons for the decline of leech therapy are complex and lie outside the scope of this paper. However, the high price and unavailability of leeches were early factors which triggered the search for cheaper alternatives. In his annual report in 1813 on medical treatments at the Sick Poor Institute, Dublin, Dr J.F. Kearney gave a remarkably detailed account of bloodletting for various contemporary diseases but leeches were not mentioned at all. ${ }^{113}$ In fact, they were too expensive to use on the Irish poor: 'among the poor everywhere these animals are scarcely ever used'. ${ }^{114}$

Dr William Stoker of the Fever Hospital in Dublin lamented their scarcity in November 1814:

The application of a sufficient number of leeches to the temples is generally effective in ordinary cases of turgescence of blood in the head, and they have been long used in this way in the hospital, with decided benefits to the patients; but from the difficulty at times of procuring them, the author first led to substitute the opening of the temporal artery.... ${ }^{115}$

In other words the unavailability of leeches increased the alternative use of mechanical bloodletting, in this case wet cupping. In 1833 Dr Jonathan Osborne of Sir Patrick Dun's Hospital recommended cupping over leeching 'in public institutions where economy is an object'. ${ }^{116}$ Similarly in 1848 , cupping in preference to leeching was justified to treat

\footnotetext{
108 'Circular of instruction No. 24, supply of leeches for use in dispensaries - Circular to boards of guardian of 6th May, 1859', in Poor Law Commission, General Order of the Commissioners for Administering the Laws of Relief of the Poor in Ireland (Dublin: Her Majesty's Stationery Office, 1870), 76-7.

109 Westmeath Examiner (Mullingar), 16 March 1889.

110 Roscommon Herald (Roscommon), 14 January 1893.

111 Irish Independent (Dublin), 19 June 1905, Contract for leeches for 1905-6.

112 Irish Independent (Dublin), 15 May 1915, Contract for leeches for 1915-16.

113 J.F. Kearney, 'Medical Report From the Physician Belonging to the Institution for Administering Medical Aid to the Sick Poor', The Belfast Monthly Magazine, 11, 62 (1813), 187-96.

114 Freeman's Journal (Dublin), 22 May 1812.

115 William Stoker, A Treatise on Fever (London: Longman, Hurst, Rees, Orme and Brown, 1815), 26.

116 J. Osborne, 'Observations on Local Blood-letting and on Some New Methods of Practising It', Dublin Journal of Medical Science, 3 (1833), 334.
} 
ophthalmia at the General Military Hospital in Dublin explicitly 'on the grounds of economy'. ${ }^{117}$

In a budgetary review at Cork Union hospital in 1863 board member Dr T. Wall 'had been looking over the list of medical requisitions and he found that fourteen dozen of leeches had been used within the last three weeks. They were expensive; and as they could be used twice or three times, he wished to know if proper care were taken of them.' Furthermore, Dr Wall asked the medical officer, 'Have you a cupping glass? because that would save the use of leeches considerably'. 118

As a final note, in contemporary Ireland as elsewhere, leeches are undergoing a revival in modern reconstructive surgery. ${ }^{119}$ This is linked to recent research on the anticoagulant hirudin and other pharmacologically active substances now known from the saliva of medicinal leeches. In the past twenty years many thousands of leeches have been used for this purpose in major hospitals throughout Ireland. Like so many commodities, the leech has been re-invented for a new market and is still contributing to Irish medical history.

\section{Conclusion}

The ongoing objective of this study is to analyse the commercial dynamics underlying the global trade in medicinal leeches in the nineteenth century. Towards this end this paper furnishes a baseline by focussing on Ireland as a microcosm of this trade, which can now be summarised as follows.

Having exhausted native sources of Hirudo medicinalis by 1750, Irish dealers imported them initially from Wales and then from France following the defeat of Napoleon. However, the bulk of the several million leeches used in Ireland in the nineteenth and well into the twentieth century came ultimately from northern Europe, via dealers in Germany and England. Specifically, leeches collected in marshes as far away as Russia made their way to wholesalers in Hamburg who transported them by ship to importers in Hull and London. These in turn transported the leeches in batches of several thousand at a time overland to Liverpool and Holyhead from which they were shipped to retailers in Dublin and Belfast. Significantly, although only a small number of dominant dealers were involved at each stage from Hamburg to Ireland, the trade was generally subject to commercial competition. This held the price of leeches to Irish hospitals at roughly 17-20s per hundred for most of the nineteenth century.

Nonetheless, the leeches imported into Ireland were considered to be very expensive and became a significant drain on hospital budgets. As such, they found little use amongst the Irish poor. Furthermore, the sheer expense of leeches affected their use by Irish medical practitioners. From the outset doctors recommended wherever practical, especially in institutions on limited budgets, to use wet cupping in preference to leeches. This was clearly motivated by economy rather than efficacy. Similarly, the expense of 'German' leeches motivated Irish dealers in the latter half of the nineteenth century to import cheaper leeches from other countries, including France, Hungary and Turkey, creating competition based on politics and national prejudices as much as cost.

${ }^{117}$ UK National Archives, Kew, WO334/15 (1848), 14.

118 Cork Examiner (Cork), 20 May 1863.

${ }^{119}$ Z. Niazi et al., 'Successful Replantation of Nose by Microsurgical Technique, and Review of Literature', British Journal of Plastic Surgery, 43, 5 (1990), 617-20; J. McCann et al, 'Microvascular Replantation of a Completely Avulsed Scalp', Microsurgery, 15, 9 (1994), 639-42. 
The question arises to what extent Ireland was truly representative of the global leech trade in the nineteenth century. In particular, did other countries throughout the world uniformly experience such high costs of leeches that they were primarily in the domain of the affluent, while at the same time cheaper alternatives were actively encouraged amongst the poor? Unfortunately, commercial aspects of the leech trade have not yet been studied in sufficient detail in any other country to make meaningful comparisons with that of Ireland.

Finally, with Ireland as a baseline, broader questions arise with regard to leech commerce which had fundamentally different parameters from that of Ireland. Most intriguingly in terms of economics, not all leech markets in the nineteenth century were freely competitive. For example, some highly significant sources of leeches, notably Morocco and Turkey, were monopolies under tight control of the respective sultans. ${ }^{120}$ Moreover, other species of leeches with markedly different biologies and transport requirements were also widely traded. For example, countries of the Mediterranean and elsewhere were supplied by a leech species (Hirudo troctina) from arid regions of North Africa. ${ }^{121}$ Similarly, counties in Asia and even the western hemisphere were supplied by a tropical species (Hirudinaria manillensis or a closely allied species) from India. ${ }^{122}$ How these and other parameters impacted the overall global trade in medicinal leeches are answerable questions.

\footnotetext{
${ }^{120}$ For example, Nation (Dublin), 6 June 1846; and New York Times (New York), 19 July 1852.

121 C. Savona-Ventura et al., 'The Medicinal Use of Leeches in Malta', Malta Medical Journal, 14 (2002), 48-52 and F.O.P. Hechtel and R.T. Sawyer, 'Toward a Taxonomic Revision of the Medicinal Leech Hirudo medicinalis Linnaeus, 1758 (Hirudinea: Hirudinidae): Re-description of Hirudo troctina Johnson, 1816 from North Africa', Journal of Natural History, 36 (2002), 1269-89.

122 R.T. Sawyer, 'The Trade in Medicinal Leeches in the Southern Indian Ocean in the Nineteenth Century', Medical History, 43 (1999), 241-5; and R.T. Sawyer et al, 'A Study in Medical History: Introduction of Medicinal Leeches into the West Indies in the Nineteenth Century', Zoosystema 20 (1998), 451-70.
} 